\title{
Purpose, Author, and Acknowledgments
}

This book brings together the topic of genocide and a comprehensive sociology of knowledge (36o degrees, as one reader suggested). The empirical focus is on the Armenian genocide.

I ask how repertoires of knowledge emerge, among Armenians and Turks and in world society, and what dynamics they unfold. Importantly, by knowledge, I do not mean certified knowledge but simply humans' taken-for-granted assumptions about the world.

Everyday exchanges, or micropolitics, lay the foundation. They involve conflicting pressures to silence, deny, or acknowledge. Knowledge entrepreneurs, actors with privileged access to channels of communication, often set the parameters for such exchanges, exercising epistemic power. Some practice radical denial, even against overwhelming evidence-a pattern that reaches beyond the issue of genocide, especially in the current era of authoritarian populism (denial of global warming is but one example).

Knowledge entrepreneurs also initiate large collective rituals to confirm a sense of community among their followers and to solidify knowledge.

Finally, when radically distinct repertoires of knowledge face one another, conflicts and struggles erupt. They unfold in distinct social fields such as politics and law, embedded in national contexts and in world society with its pronounced human rights scripts since the end of World War II.

Each of these points is the subject of one or more chapters of this book. The final chapter argues that denialism in the context of (partial) human rights hegemony likely produces effects that are counterproductive in the eyes of those who deny mass atrocities.

Now a few words about me, the author, and about institutions and individuals who contributed, speaking to the context and conditions of this book's production of knowledge about genocide knowledge. 


\section{THE AUTHOR}

I was born in 1951, six years after the end of the Shoah, in a small conservative town in Germany, the country of the perpetrators. I grew up in a world in which World War II was an ever-present, albeit somber, theme, unavoidably in light of the physical traces it had left and the missing family members. It was also a world in which our elders, at home, in school, and in much of the public sphere, thoroughly silenced the Holocaust. Only in the late 1960s did my generation begin to learn, in piecemeal fashion, the horrifying facts of the Shoah. As children of the perpetrator generation, we acquired cultural trauma; we were horrified, shaken in our basic assumptions about the world we lived in and about our elders.

This exposure preceded, by a few years, my entry into the study of sociology, economics, and public policy at the University of Cologne (Köln), continued in the doctoral program of the University of Trier. A series of positions, including postdoctoral fellowships at Johns Hopkins and Harvard universities and employment at the University of Bremen and at the Criminological Research Institute of Lower Saxony (KFN) in Hanover, led to my appointment as a professor at the University of Minnesota. Along the way, I specialized in the sociology of law and criminology and worked on various issues, such as white-collar crime legislation, sentencing guidelines, comparative punishment rates, and the sociology of criminology. Only the events of the 1990s, with their genocides and international criminal tribunals, enabled by the end of the Cold War, encouraged me to apply my professional expertise to issues that had preoccupied me for decades, as a private person and as a citizen. Biography met history, and a new line of work resulted.

I began to examine how legal proceedings color collective representations and memories of mass violence. That work is reflected in my books American Memories: Atrocities and the Law (with Ryan D. King, Russell Sage Foundation, 2011) and Representing Mass Violence: Conflicting Responses to Human Rights Violations in Darfur (University of California Press, 2015). I developed an undergraduate course on violations of human rights norms and wrote a small accompanying volume (Crime and Human Rights: Criminology of Genocide and Atrocities, Sage, 2010), supplemented by a graduate seminar in the sociology of knowledge and collective memory. I organized the latter along a line of theoretical approaches that provide the structure of this book. The seminar inspired several dissertation projects and motivated the writing of this sociology of genocide knowledge.

\section{ACKNOWLEDGMENTS}

The present book was made possible by particular opportunities, including residences at two institutes for advanced study, funding and other support, critiques and inspiration by colleagues, and collaboration with research assistants. 
The Arsham and Charlotte Ohanessian Chair at the University of Minnesota provided me with resources to advance a research agenda through several interlinked projects that helped me to examine many of my expectations in light of empirical evidence. Outside of Minnesota, I benefited from 2018-19 fellowships at the Stellenbosch Institute for Advanced Study (STIAS) in South Africa and at the Institut d'Études Avancées de Paris (IEA) in France, the latter with the financial support of the French State, programme "Investissements d'avenir," managed by the Agence Nationale de la Recherche (ANR-11-LABX-0027-01 Labex RFIEA+).

The institutes, with their facilities and staff, provided ideal environments for writing and for exchanges with colleagues from many countries and disciplines, guarding against parochialism. STIAS enhanced my understanding of other societies' engagement with dark pasts. Many fellows, especially from diverse parts of the African continent, enriched my experience. The IEA served as a basis from which to engage with the rich intellectual life of Paris and to reach out to civil society and political actors. I built on benefits received during the summer of 2016 as a guest of the Fondation de la Maison des Sciences de l'Homme.

More individuals than I can mention merit special mention. I ask those left out for forgiveness. The names of numerous interviewees in Paris, Massachusetts, and Minnesota have to remain anonymous. To them I am especially grateful.

In Paris, Liora Israël and Jacques Commaille laid the foundation for a series of successful research visits, and John Hagan and Philip Smith helped pave the way to the French capital. Boris Adjemian, Olivier Baruch, Johann Michel, Claire Mouradian, Jacques Semelin, Michel Wieviorka, and Julien Zarifian enriched my understanding of French-Armenian history, genocide knowledge, and memory legislation.

At the IEA, Saadi Lahlou, as director, created an intellectually engaged atmosphere. Gretty Mirdal, previous director and guarantor of continuity, enriched the experience with her intellect and personal warmth. Simon Luck's advice was decisive in guiding us through (what may appear to outsiders as the jungle of) Parisian academic life. Many fellows, especially those concerned with issues of violence, enriched my thought. Hakan Seckinelgin merits special mention. We worked on related fronts, co-organized events, and co-adventured into Parisian intellectual life. Kei Hiruta, Michael Jonik, Andrew Kahn, Adam Mestyan, and Penny Roberts explored painful histories of violence, and I appreciated their solidarity. Many conversations with Gregory Bochner (on realism), Denis Walsh (on agency), Marylène Lieber (on gender), and Adam Frank (on intersections of art and intellectual life) provided further inspiration.

At STIAS, the former and incoming directors, Hendrik Geyer and Edward Kirumira, stimulated intellectual and social life. Christoff Pouw provided us with access to sectors of South African society that would have been difficult to gain without his help. Fellow Fellows Duncan Brown, Kelvin Campbell, Manuel Castells, Abdallah Daar, Charles Fombad, Peter Gärdenfors, Nkatha Kabira, 
Marlize Lombard, Susanne Lundin, Henrietta Mondry, and Izuchukwu Ernest Nwankwo are among those who provided inspiration and community. Chielozona Eze, philosopher, literary scholar, survivor of the Biafra War, and author of Survival Kit, became a special companion.

At the University of Minnesota, Ohanessian Chair funds allowed me to bring to campus, as Annual Ohanessian lecturers, Bedross Der Matossian, Timothy Snyder, and Fatma Müge Göçek. Each enriched me far beyond the moment of their visit. I am grateful to Dean Jim Parente, who awarded me the Chair, and Dean John Coleman for twice extending the term.

The Ohanessian Chair, supplemented by a series of grants, including a Human Rights Initiative grant, Graduate Student-Faculty Collaborative grants, Undergraduate Research Opportunity grants, and first-year student opportunity grants, allowed me to work with several gifted undergraduate and graduate students as research assistants. They are impressive young people and their contributions to this project are essential. I am most grateful for their engaged work.

Graduate student Brooke Chambers was a crucial collaborator, especially on the Griswold v. Driscoll court case. She collected the data and contributed to the writing up of results. Accordingly, Brooke became coauthor of chapter 8. Caitlin Barden, then an undergraduate student at Minnesota, now a successful lawyer, had collected basic information, on which Brooke and I were able to build. Jacqulyn Kantack (then Meyer), as an undergraduate research assistant, did impressive work analyzing French legislative records. Jackie has since earned her Master of Human Rights degree and works with Human Rights Watch.

Prashasti Bhatnagar, now a graduate student in a joint program at Georgetown and Johns Hopkins universities, worked in the Minnesota History Archives, tirelessly and reliably. Dr. Lou Ann Matossian, eminent Minnesota historian with an unparalleled knowledge of the history of Armenians in her state, provided the lead to the Thomas and Carmelite Christie files in the Minnesota History Archives.

Several undergraduate and graduate research assistants contributed admirably to the coding of media reports and VAN (Vigilance Arménienne contre le Négationnisme) data and to the analysis of resulting data sets. They include, again, Brooke Chambers, Jessica Faulkner, Erez Garnai, Miray Phillips, Renée Rippberger, and Ellie Stencel. Abby Vogel and Kate Dwyer did outstanding work analyzing a set of documentary films on the Armenian genocide and Armenian survivor interviews from the Shoah Visual Archives, respectively.

Erez Garnai accompanied this project with his organizational abilities, his artistic skill in the preparation of graphs and tables, and his editorial care for detail. His outstanding work on my book Representing Mass Violence, early in his graduate studies, suggested that I employ him again for this book (now, as he gets ready to defend his dissertation).

Intellectual inspiration is hard to trace. I do know that John Hagan motivated me to work on issues of mass violence a good dozen years ago. He must have done 
a convincing job, as this is the fourth book I have since written on related themes. David Garland's insights into the interaction between elite actors and conditions of people on the ground, articulated for the realm of criminal punishment, inspired my thoughts on similar interactions in the formation of genocide knowledge. Jeffrey Olick and Daniel Levy invited me into the world of memory studies. At Minnesota, Alejandro Baer, director of our Center for Holocaust and Genocide Studies (CHGS) and descendant of refugees from Nazi Germany, is my companion in the intellectual journey through this challenging and painful terrain. I also benefited from advice by Artyom Tonoyan, CHGS research fellow, who combines sociological insight with profound knowledge of Armenian affairs. Past coauthorships on related issues with former advisees Ryan King and Hollie Nyseth Brehm (both now on the faculty of The Ohio State University), Wenjie Liao (Rochester Institute of Technology), James Nicholas Wahutu (New York University), and Susan McElrath (Montana State University) have undoubtedly affected this work as well, as did collaboration with current advisees Jillian LaBranche, Brooke Chambers, Nir Rotem, Michael Soto, and Nikoleta Sremac.

I am especially grateful to Alejandro Baer and Philip Smith, who read parts of an earlier draft of the manuscript, and to Pamela Feldman-Savelsberg, who closely read the final version, all providing most helpful feedback. Fatma Müge Göçek and Lois Presser reviewed the initial submission to UC Press. They waived their anonymity, enabling communication where I had questions. They went far beyond the call of duty. I thank them for their detailed and profound criticism and suggestions. I, of course, am solely responsible for any remaining imperfections or mistakes.

Maura Roessner, my editor at UC Press, combines professionalism and enthusiasm in ways that instill confidence in authors who have the good fortune of working with her and her colleagues, especially Jessica Moll and Madison Wetzell, reliable communicators. I am most grateful to Richard Earles for his thorough and masterful work as copy editor.

Finally, Pamela Feldman-Savelsberg accompanied me every step along the way, at home, sometimes in the office (at times hard to keep apart), in Minneapolis/ Saint Paul, Stellenbosch, Paris, and Berlin, through smooth and difficult stretches, always between cultures. I am more grateful than I can ever say. To her, I dedicate this book.

Joachim J. Savelsberg

Stellenbosch, South Africa / Paris, France /

Twin Cities of Minnesota, 2018-20 